Aldo Clerico*, Martina Zaninotto, Andrea Ripoli, Silvia Masotti, Concetta Prontera, Claudio Passino and Mario Plebani, on the behalf of the Study Group on Cardiovascular Risk Biomarkers of the Italian Society of Clinical Biochemistry (SIBioC)

\title{
The 99th percentile of reference population for cTnl and cTnT assay: methodology, pathophysiology and clinical implications
}

DOI 10.1515/cclm-2016-0933

Received October 14, 2016; accepted February 28, 2017; previously published online April 12, 2017

Abstract: According to recent international guidelines, including the 2012 Third Universal Definiton of Myocardial Infarction by the Joint ESC/ACCF/AHA/WHF Task Force, an increase in cardiac troponin (cTn) levels over the 99th percentile upper reference limit (99th URL) should be considered clinically relevant, this cut-off being measured with an imprecision $\leq 10 \mathrm{CV} \%$. In theory 99th URL values strongly depend not only on demographic and physiological variables (i.e. criteria for considering the reference population "healthy"), but also on the analytical performance of cTn methods and mathematical algorithms used for the calculation. The aim of the present article was therefore to review the methodological and pathophysiological factors affecting the evaluation and calculation of the 99th URL for cTn assay. The critical analysis made showed that no uniform procedure is followed, and nor have experts or regulatory bodies provided uniform guidelines for researchers or cTn assays manufacturers as an aid in "their quest to define normality". In particular, little attention has been paid to the way in which a healthy reference population is to be selected, or the criteria for calculating the 99th URL value for cTn assays, thus highlighting the need for international recommendations not only for demographic and physiological variables criteria

*Corresponding author: Professor Aldo Clerico, MD, Laboratory of Cardiovascular Endocrinology and Cell Biology, Department of Laboratory Medicine, Fondazione CNR Toscana G. Monasterio, Scuola Superiore Sant'Anna, Via Trieste 41, 56126 Pisa, Italy, E-mail: clerico@ftgm.itr

Martina Zaninotto and Mario Plebani: Department of Laboratory Medicine, University-Hospital, Padova, Italy. http://orcid.org/00000002-0270-1711 (M. Plebani)

Andrea Ripoli, Silvia Masotti, Concetta Prontera and Claudio Passino: Fondazione CNR Regione Toscana G. Monasterio and Scuola Superiore Sant’Anna, Pisa, Italy for defining a healthy reference population, but also for calculating mathematical algorithms for establishing/ calculating clinical decision values. An expert consensus group, comprising laboratory and clinical scientists, biomedical statisticians, industrial and regulatory representatives, should be responsible for drawing up these guidelines.

Keywords: cardiac troponins; gender specific decision values; highly sensitive immunoassay; quality specification; reference population.

\section{Introduction}

The international guidelines "on the Redefinition of AMI", issued in the year 2000 by the Joint European Society of Cardiology/American College of Cardiology Committee, recommended that an increase in cardiac troponin I (cTnI) or cTnT levels outside the 99th percentile upper reference limit (99th URL) should be considered clinically relevant, and indicated that this cut off value should be measured with an imprecision of $\leq 10 \mathrm{CV} \%$ [1]. Subsequently the guidelines for the Universal Definition of Myocardial Infarction, edited by the joint ESC/ACCF/AHA/WHF task force in 2007 [2] and 2012 [3], confirmed that cTnI and cTnT are the preferred biomarkers for the differential diagnosis of acute coronary syndrome (ACS), and also that the 99th URL value should be measured with an imprecision of $\leq 10 \mathrm{CV} \%$.

Quality specifications for troponin assay require the presence of measurable cTnI and cTnT, also in the blood of healthy subjects [4-6]. However, measurement of the 99th URL of cTnI and cTnT levels is a challenging analytical issue due to low biomarker concentrations present in healthy subjects [7-9]. Only after 2006 some manufacturers set-up the first new generation of cTnI and cTnT immunoassays with improved analytical sensitivity in accordance 
with the quality specifications indicated in international guidelines and consensus documents [4, 6-16]. Importantly, highly sensitive methods should also be able to measure troponin levels in the majority of healthy adults subjects $(>50 \%)$, as suggested in some consensus documents [16-18]. In order to measure the extremely low circulating levels of the biomarker in all healthy subjects, a highly sensitive method for $\mathrm{cTnI}$ or $\mathrm{cTnT}$ should have a low detection limit greatly lower than $5 \mathrm{ng} / \mathrm{L}$ [8].

Currently few methods able to completely meet the quality specifications recommended by international guidelines are commercially available for cTn assay [9, 16-18]. In one case, for example the manufacturer reports that the limit of blank (LoB) and limit of detection (LoD) for the highly sensitive cTnT method are $2.16 \mathrm{ng} / \mathrm{L}$ and $4.72 \mathrm{ng} / \mathrm{L}$, respectively, using the Elecsys 2010 and the Cobas e411 analyzers and $1.36 \mathrm{ng} / \mathrm{L}$ and $2.05 \mathrm{ng} / \mathrm{L}$, respectively, using the MODULAR ANALYTICS E170, Cobas e601 and Cobas e602 platforms, respectively (package insert of Troponin T hs REF 05092744 190, 2016-06, V7.0, Roche Diagnostics GmbH, Mannheim, Germany). On the other hand, the "STAT Architect highly sensitive TnI" method shows LoB, LoD and LoQ (quantitation limit at 10\% CV) values of about $0.7 \mathrm{ng} / \mathrm{L}, 1.3 \mathrm{ng} / \mathrm{L}, 5.0 \mathrm{ng} / \mathrm{L}$, respectively, as reported by the manufacturer (package insert of STAT Highly sensitive Troponin I, REF 3P25, B3P250, G1-0139/ R02), and in two studies in the literature (Table 1) [14, 15].

The most important analytical characteristic for a highly sensitive troponin assay, is the ratio between the 99th URL and LoQ values at $10 \% \mathrm{CV}$, which should be greater than 1 [5]. Considering that the 99th URL value for the cTnI Architect method recommended by manufacturer is $26.2 \mathrm{ng} / \mathrm{L}$, this value is 4-fold higher than the LoQ at $10 \%$ CV. Furthermore, the 99th URL value (i.e. $26.2 \mathrm{ng} / \mathrm{L}$ ) is measured by the Architect method with an imprecision of about 5\% CV (Figure 1), which is half the imprecision required by international guidelines for the 99th URL value (i.e. 10\% CV) [NaN]. The Architect method can also detect cTnI levels that exceed LoD in more than $85 \%$ of healthy subjects including children and adolescents [14, 15], as requested by some consensus documents [16-18]. These data, shown in Table 1 and

Table 1: LoB, LoD and LoQ values of hs-STAT Architect immunoassay for cTnl.

\begin{tabular}{lrrr}
\hline Reference & LoB, ng/L & LoD, ng/L & LoQ CV $10 \%$, ng/L \\
\hline Manufacturer & $0.7-1.3$ & $1.1-1.9$ & 4.7 \\
Krintus et al. [14] & $0.7-1.3$ & $1.1-1.9$ & $4.6-8.1$ \\
Caselli et al. [15] & 0.7 & 1.3 & 4.7 \\
\hline
\end{tabular}

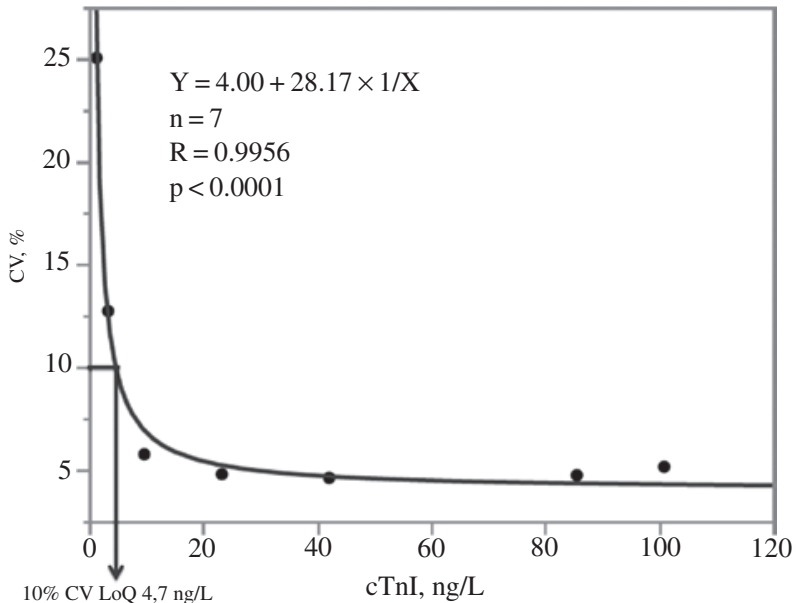

Figure 1: Imprecision profile of the Architect method for cTnl assay. The imprecision profile was obtained in the Authors' laboratory by measuring in 39 different runs seven plasma pools collected from healthy subjects and patients with cardiac disease using three different lots of reagents and calibrators throughout 2 months.

Figure 1, clearly indicate that the Architect method has the analytical performance required for a true highly sensitive method for cTnI assay.

There are further methodological considerations to take into account in explaining the great differences between the analytical performances between the cTn assay methods reported in the literature. There is no general consensus on the evaluation and calculation of the imprecision profile and, consequently, of the LoQ value [19]. Manufacturers and authors often fail to report in detail how the imprecision profile and LoQ at $10 \% \mathrm{CV}$ values are calculated. Even international CLSI guidelines $[20,21]$ for the evaluation of the imprecision profile have some limitations, especially when between-runs variability, requiring multiple recalibrations, is recommended [19]. The seminal studies by Spencer et al. [22] on TSH immunoassays clearly demonstrate that the imprecision profile of immunometric assays strongly depends on the number of reagents lots and instrument calibrations involved; these data suggest that lot-to-lot variation of material and calibrators have an impact on the calculation of 99th URL values. Spencer et al. [22] also recommend that betweenruns ( $\mathrm{n}>10$ runs) imprecision should be evaluated across 6-8 weeks, using more than one batch of reagent, and more than one calibration instrument.

Furthermore, LoQ values (10\% or $20 \%$ CV) can vary significantly when different functions are used for fitting the relationship between response error (i.e. CV\%) and the level of response (i.e. analyte concentration), such as straight line, parabolic functions, power equations or variance models, using three or four parameters [19]. For 
example the data reported in Figure 1 give a value of 4.7 $\mathrm{ng} / \mathrm{L}$ for LoQ at $10 \%$ if fitted by a reciprocal function (as shown), but a value of $6.5 \mathrm{ng} / \mathrm{L}$, if the same data are fitted by a power function (i.e. $Y=19.764{ }^{\star} \mathrm{X}^{-0.359}$ ), which actually shows a worse fit.

The study by the Committee on Standardization of Markers of Cardiac Damage of the IFCC, published in 2004, found a difference of up to 20-fold between the 99th URL values of cTnI and cTnT immunoassays [5]. Despite the great improvement achieved in the analytical performance of cTnI immunoassays over the last few years [8], two recent studies demonstrated the persistence of great systematic differences between the results of commercial cTnI methods (on average up to more than 2-fold) [9, 23]. The lack of harmonization among the troponin immunoassay methods may generate confusion in physicians, with a consequent misinterpretation of $\mathrm{cTnI}$ and cTnT results $[8,23,24]$.

The aim of the present article was therefore to review and make a critical analysis of the methodological issues and pathophysiological mechanisms affecting the evaluation and calculation of 99th URL for cTn assay.

\section{Criteria for calculating 99th URL values}

It is conceivable that 99th URL values not only strongly depend on demographic and physiological variables (i.e. the criteria for considering the reference population "healthy") [17, 25-29], but also on the analytical performances of cTn methods, as well as on the mathematical algorithms used for calculating the 99th URL $[10,14,15$, $17,18,25,26]$.

\section{Criteria for selecting reference population}

The approach for selecting a reference population for calculating the 99th percentile value for cTn assays has not yet been adequately defined [17]. The Third Universal Definition of Myocardial Infarction [3] reported that gender-dependent values might be recommended for highly sensitive troponin assays without specifying criteria for considering a population "healthy". The ESC guidelines issued in 2010 [30] state that the calculation of the 99th percentile is markedly affected by outliers; consequently, to reach a $95 \%$ confidence value in the 99th URL calculation, a sample size of at least 300 individuals per group is required [31]. They also state that meeting these requirements is challenging and costly, and most laboratories have no resources to perform studies to identify troponin reference limits [30]. The ESC guidelines [32], issued in 2016 for the management of ACS in patients without persistent ST-segment elevation, fail to address this issue [32].

\section{Age}

Several studies appearing since 2005 have used the first generation of immunoassay methods with increased analytical sensitivity for cTnI and cTnT assay, and have demonstrated that measurable troponin values are present in blood of the majority of healthy adults [7, 8]. Thanks to the ensuing improvement achieved in the analytical sensitivity of immunoassay methods, it is now possible to detect cTnI and cTnT levels throughout the lifespan, from birth to senescence [9-15, 17, 18, 33, 34].

Regarding the pediatric age, some studies issued since 2012 using the highly sensitive method with Architect platform, demonstrated that cTnI levels (i.e. concentration values higher than the $\mathrm{LoD}$ value of $1.3 \mathrm{ng} / \mathrm{L}$ ) were clearly evidenced in more than $85 \%$ of a population of apparently healthy children (ages ranging from birth to adulthood) when a highly sensitive method was used for troponin measurement $[15,33,34]$. cTnI levels, at their highest in the first few weeks of life, tended to gradually decrease up to adulthood [15] (Table 2 and Figure 2). From a physiological viewpoint, these data suggest that $\mathrm{cTnI}$ is released from cardiomyocytes throughout the pediatric age, probably in relation to physiological growth. However, further studies are needed to confirm these preliminary data, and to establish cTnI reference intervals from neonatal age to adolescence. As yet no reference interval data are available for cTnT in the pediatric age, circulating levels being mainly below the LoD value of ECLIA method for cTnT assay [26].

Several studies published in the time period between 2005 and 2010 report that cTnI levels progressively

Table 2: cTnl values of neonates, children and adolescent subjects according to age measured with the high sensitive method using the ARCHITECT platform, according to reference [15].

\begin{tabular}{lrrr}
\hline Age & Number & Median, ng/L & Range, $\mathbf{n g} / \mathbf{L}$ \\
\hline $1 \leq$ days $<30$ & 36 & 21.5 & $12.9-44.0$ \\
$1<$ months $\leq 12$ & 57 & 11.5 & $5.7-21.7$ \\
$1<$ years $\leq 10$ & 65 & 2.2 & $1.6-2.8$ \\
$10<$ years $\leq 18$ & 221 & 2.0 & $1.5-2.8$ \\
$0<$ years $\leq 18$ & 379 & 2.5 & $1.7-6.2$ \\
\hline
\end{tabular}




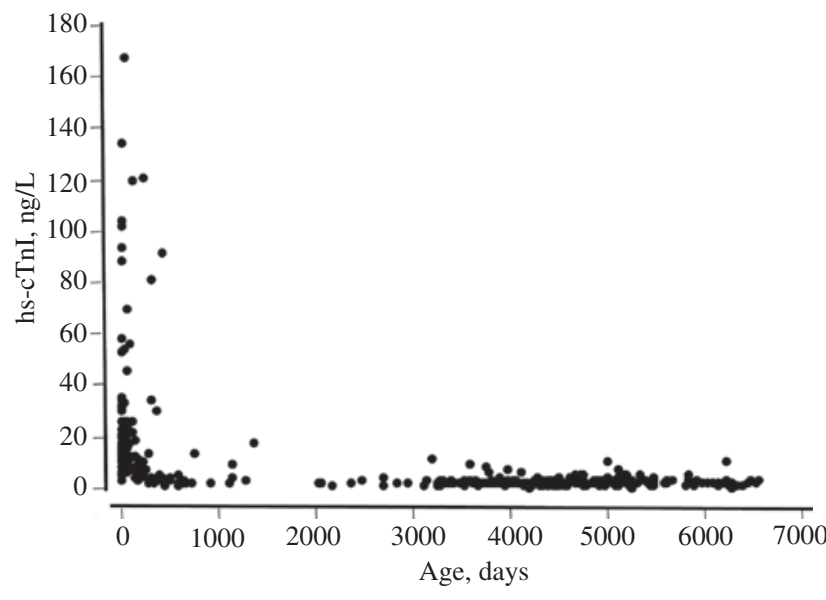

Figure 2: cTnl concentrations measured with highly sensitive ARCHITECT assay in apparently healthy neonates, children and adolescents.

increase in apparently healthy adult subjects aged over 65 years $[10,13]$. This finding was confirmed in studies using the highly sensitive cTnI method [14, 27]. The progressive increase of circulating cTnT levels in apparently healthy adult subjects over 65 years was confirmed in the same period, when the highly sensitive ECLIA method became commercially available [11, 12, 26, 35-37]. In their study on a total of 651 subjects admitted to emergency department (ED) without evident conditions known to increase cTnT, Hammarsten et al. [36] found cTnT values over the cut-off (i.e. $14 \mathrm{ng} / \mathrm{L}$ ) in $9 \%$ of subjects admitted to ED, most of whom ( $>90 \%)$ were $\geq 65$-year olds. Furthermore, in subjects aged $<65$ years admitted to ED without evident conditions known to cause an increase in cTnT, the 99th cTnT percentile was $12 \mathrm{ng} / \mathrm{L}$, with little age dependence whereas the 99th cTnT percentile, at $82 \mathrm{ng} / \mathrm{L}$, was highly age dependent in subjects aged $\geq 65$ years [36].

The ESC international guidelines on the use of highsensitivity cTn in acute cardiac care, published in 2010 [30], indicated that the reference population should ideally have negative exercise stress tests and normal cardiac function assessed by imaging without providing further specifications regarding the age range of subjects enrolled. Nor do the 2012 ESC guidelines [38] or the Third Universal Definition of Myocardial Infarction [3] take into account the issue of the definition of the reference population for calculating the 99th URL.

Due to the difficulty involved in enrolling truly healthy subjects aged $\geq 65$ years $[17,26]$, the 99th URL values for $\mathrm{cTnI}$ and $\mathrm{cTnT}$ reported in clinical studies or by manufacturers are commonly calculated in populations aged between 20 and 65 years, usually recruited from blood donors. For example, in the instruction manual, the manufacturer of the highly sensitive ECLIA method reports that the 99th URL value of $14 \mathrm{ng} / \mathrm{L}$ (limit of confidence at 95\%: 12.7-24.9 ng/L) was calculated in a population of 533 healthy volunteers without specifying gender and age range (instruction manual: Troponin $\mathrm{T}$ hs, REF 05092744 190, 2011-02, V4, Roche Diagnostics). Yet in the instruction manual of the ARCHITECT STAT Highly sensitive Troponin-I (package insert of STAT Highly sensitive Troponin I, REF 3P25, B3P250, G1-0139/ R02, Abbott Diagnostics), the manufacturer indicates two 99th URL values differentiated on the basis of gender, reporting that the reference population comprised 765 females (age range, 21-75 years; 99th URL 15.6 $\mathrm{ng} / \mathrm{L}$ ) and 766 males (age range, 21-73 years; 99th URL $34.2 \mathrm{ng} / \mathrm{L}$ ), respectively.

In view of the above, the 99th URL values of highly sensitive methods for cTnI and cTnT currently used in clinical practice are underestimated for age $[35,39,40]$. Data reported by Franzini et al. [26], for example, show that the calculated 99th URL values for cTnT ECLIA method in apparently healthy elderly men and women (>65 years) were $36.8 \mathrm{ng} / \mathrm{L}$ and $28.6 \mathrm{ng} / \mathrm{L}$, respectively, whereas the 99th URL value advocated by the manufacturer is $14 \mathrm{ng} / \mathrm{L}$. Furthermore, Gore et al. [41] reported that the use of a uniform $14 \mathrm{ng} / \mathrm{L}$ cutoff for the hs-cTnT assay may lead to over-diagnosis of AMI, particularly in men and the elderly.

In theory, the use of underestimated 99th URL values in clinical routine should increase clinical sensitivity, but decrease troponin assay specificity [42]. This issue is of great clinical relevance in view of the fact in ED patients an enormous number of cardiac and even extra-cardiac clinical conditions are associated with cTnI or cTnT levels higher than 99th URL $[1-3,38]$. Indeed, according to Giannitsis and Katus [40], only about $40 \%$ of patients admitted to ED with at least one troponin value over the 99th URL measured by highly sensitive methods actually has AMI.

Higher circulating levels of cTnI and cTnT in elderly healthy subjects might be caused by an increased release of these proteins from cardiomyocytes, by a decreased turnover (e.g. due to reduced glomerular filtration rate), or by the combined action of these two mechanisms. Indeed, as recently shown in detail [43, 44], several age-associated disorders can cause the death of cardiomyocytes, with the consequent release of sarcolemma proteins, including cTnI and cTnT. On the other hand, circulating cTnI and cTnT are fragmented into molecules small enough to be cleared by the kidney of healthy subjects [45]. However, there is little evidence that decreased renal clearance can increase cTn levels [46]. 


\section{Gender}

Only after 2007, thanks to the availability of the first highly sensitive cTnI and cTnT methods, it was possible to demonstrate that circulating troponin values are genderdependent [10]. In a study published in 2008 [7] on 692 apparently healthy subjects ( $311 \mathrm{M}, 381 \mathrm{~F}$; mean age 45.3 [range 11-89] years), a significant difference was found between men and women for cTnI values ( $\mathrm{M}$, median 12 [range 7-96] ng/L; F, median 8 [range 7-130] ng/L) using the ADVIA TnI-Ultra method (Laboratory Diagnostics Siemens Healthineers); undetectable cTnI values $(<7 \mathrm{ng} / \mathrm{L})$ were found in 168 individuals $(24.3 \%$ of total samples). Gender-dependent cTnI values were also found in another study [47], using a prototype Access AccuTnI assay (Beckman-Coulter Diagnostics) to assess the distribution of cTnI results in a population of elderly individuals (PIVUS [Prospective Study of the Vasculature in Uppsala Seniors] study; $\mathrm{n}=1005)$. At multivariable logistic regression analysis, applied to the entire study population, male gender was also independently associated with detectable cTnI levels of $>6 \mathrm{ng} / \mathrm{L}$ [47].

In 2009, a gender-dependent difference in 99th URL for the highly sensitive cTnT assay (Roche Diagnostics) was also reported by Mingels et al. [48] in a reference population of 479 apparently healthy individuals; the observed 99th percentile was $8 \mathrm{ng} / \mathrm{L}$ in 215 females, and $18 \mathrm{ng} / \mathrm{L}$ in 264 males. Results from larger studies [12, 26] confirm the dependence of cTnT values on gender.

A more satisfactory definition of differences in cTnI circulating levels according to gender and age is now available thanks to the highly sensitive method using the ARCHITECT platform, able to measure biomarker values above the LoD value in the majority of healthy subjects from the day of birth to senescence [14, 15, 33, 34, 49-51]. No studies found significant gender-related differences in cTnI values of pediatric age subjects (Table 2 and Figure 2) $[15,33,34,50]$. On the other hand, adult males usually present cTnI values that are, on average, twofold higher than those in women; in this age group, the calculated 99th URL values are strongly gender-dependent $[14,29,49]$.

Regarding the elderly, Eggers et al. [27] measured cTnI values with the highly sensitive ARCHITECT method in a cohort of 814 participants both at baseline (men age 70.2 [SD 0.2] years, $49.5 \%$ males) and after a 5-year follow-up. Even in the 382 participants who were without cardiovascular disease at the age of 75 years, the 99th percentile increased from $31.6 \mathrm{ng} / \mathrm{L}$ to $51.3 \mathrm{ng} / \mathrm{L}$ (relative increase, $62 \%)$. cTnI values were higher in males $(n=403$; median: $4.1 \mathrm{ng} / \mathrm{L}$, range $25 \mathrm{th}-75$ th percentiles: $3.0-6.4 \mathrm{ng} / \mathrm{L}$ ) than females ( $\mathrm{n}=411$; median: $3.0 \mathrm{ng} / \mathrm{L}$, range 25th-75th percentiles: 2.2-4.1 ng/L) [27]. Furthermore, at unadjusted logistic regression, male gender, NT-proBNP and left ventricular mass index were significantly associated with an increase in cTnI concentrations [27].

\section{Surrogate biomarkers}

Sandoval and Apple [17] recommended an approach involving clinical history and some biomarker surrogates (including hemoglobin $A_{1 c}$, natriuretic peptides, serum creatinine for eGRF calculation, and cardiac imaging) for the definition of healthy individuals. In particular, Zeller et al. [29] showed that the removal of subjects with increased NT-proBNP from the reference cohort has a dramatic effect on the 99th URL value, while the effect of the addition of further exclusion clinical criteria (beyond increased levels of B-type natriuretic peptides) is negligible. Other authors reported that values of natriuretic peptides (i.e. BNP or NT-proBNP) within the normal reference range are a prerequisite for defining a normal reference population [8, 26]. Accordingly, Sandoval and Apple [17] recommended the measurement of B-type natriuretic peptides as main surrogate marker of myocardial dysfunction for defining a healthy reference population.

\section{Physical exercise}

As is well known, not only age and gender, but also physical exercise can affect circulating cTnI and cTnT levels in apparently healthy subjects [25]. In a recent review [25], 145 studies were recovered in a systematic search. The data obtained showed that cTnI and cTnT circulating levels rise in healthy subjects not only after prolonged endurance exercise (e.g. marathon, cycling competition, mountain bike racing, ski endurance race and triathlon), but also after short-term and intermittent exercise (e.g. 30-minutes' running and basketball) [25].

Variations in cTnI and cTnT values can be related not only to the type of physical exercise (e.g. intensity and level of training), but also to blood sample timing [52]. Moreover, the method used to measure the troponin levels can affect results [25]: due to the low circulating levels of cTnI and cTnT in healthy subjects, only highly sensitive methods allow the accurate evaluation of biomarker variations in the majority of subjects tested, especially when pre- and post-exercise values are both below the 99th URL [8, 25]. Importantly, almost $100 \%$ of subjects demonstrated a significant increase in circulating levels after 
exercise, especially when highly sensitive methods were employed [25, 52-56].

From a clinical viewpoint, some studies reported that increased troponin levels can be detected not only during or few minutes after the exercise, but also hours after strenuous physical effort $[25,52]$. Therefore it is important to check whether each subject/patient has performed intense physical activity before cTn measurement. Troponin release after effort stress test may allow the identification of a subset of subjects at an increased risk of heart failure [57-59], and standardized physical effort with consequent cTn release variations may play an important prognostic role in patients with heart failure $[57,58]$.

\section{Biological variation}

There is consensus in international guidelines $[1-4,16$, $30,32,38]$ that the assessment process for diagnosing AMI includes collection of two or more blood samples for the detection of relative or absolute changes in cTn concentrations. It is widely believed that biological variations in cTnI and cTnT might affect the accurate determination of rises and falls in biomarker values after acute myocardial injury [38,60]. As cTn has a low individuality index [60], a serial change in hs-TnI or hs-cTnI levels (using 99th percentile diagnostic cut-off) 0 to $3 \mathrm{~h}$ after admission may facilitate an early diagnosis of AMI [61]. Furthermore, a recent study [62] reported that biological cTnI variation is not dependent on the time interval between sample collections. These studies [61, 62] confirm that serial change in troponin concentrations is a useful tool for rapidly identifying ED patients at a low risk of ACS.

\section{Statistical considerations}

The different approaches used for calculating the 99th URL value are a potential cause of apparent contradictions in available studies, several of which report considerable differences in the 99th URL values of cTnI and $\mathrm{CTnT}$, depending on the statistical approach used for their calculation [17, 26-31, 49, 63-65]. As outliers can markedly affect the calculation of 99th URL value, the Study Group on Biomarkers in Cardiology of the Acute Cardiovascular Care Association of the European Society of Cardiology [30] recommend a sample size of at least 300 individuals per group for the calculation of 99th URL. This relatively large number is pre-requisite for ensuring a $95 \%$ probability that at least $99 \%$ of the population will have values below the highest observed troponin value [31]. According to Sandoval and Apple [17], the enrollment of more than 2000 individuals may be required to reliably establish the 99th URL value for population samples characterized for several age, gender and ethnicity sub-groups. It is therefore reasonable to consider the large majority of studies reporting 99th URL values for cTnI and cTnT statistically underpowered [17].

Parametric and non-parametric methods are usually used to calculate the 99th URL [26-29, 49, 63-69]. As they are recommended in the EP28-A3c IFCC-CLSI document [66], non-parametric methods are the more commonly used statistical approach in studies reporting the 99th URL values [17], but they do call for large samples, and the reliability of their results may be compromised by some outliers present in the database. The IFCC-CLSI document [66] suggests the robust percentile method as an alternative, especially for small cohorts. Another approach might be the use of robust iterative statistical (e.g. bootstrap) methods [67], which minimize the effect of extreme values and may also be suitable for small samples, but do necessitate collaboration from an expert statistician. However, the most important issue regarding 99th URL calculation is the identification of outlier values. The EP28-A3c IFCC-CLSI document [66] suggests that Dixon's method could be used to address this issue [69], but results obtained using other procedures, the Tukey method in particular [26, 65], have also been reported $[67,68]$. Whatever the statistical approach used, the most reliable possible results will probably be obtained only by using the largest possible population groups, which should be accurately screened according to ethnic, demographic and clinical criteria [17].

The EP28-A3c IFCC-CLSI document [66] stresses that it is essential to make an assessment of interference from naturally occurring constituents in blood samples of a reference population. It is well known that interferences from, for example troponin macro-aggregate [70, 71] and heterophilic [72] or auto-antibodies [73], may produce aberrant results in troponin testing in individual samples. Finally, the EP28-A3c IFCC-CLSI document [66] recommends that all pre-analytical factors (including subjects preparation, sample collection and processing), the analytical method procedure (including lot-to-lot variation of materials and calibrators) and instrumentation must be carefully defined and used for testing the reference individuals in order to minimize the number of aberrant results. 


\section{Mechanisms of troponin release in cardiac patients and healthy subjects}

Some pathophysiological factors should be borne in mind when comparing and explaining the differences in cTn release in ischemic and non-ischemic injury in patients with cardiac disease [74-76] and that in healthy patients following physical exercise. The kinetic profile of cTnI and cTnT circulating levels after strenuous exercise in apparently healthy subjects $[25,40,52-56,77-90]$ is different from that usually observed in patients with AMI. It is well known that circulating levels of cTnI and cTnT in patients with uncomplicated type 1 AMI usually peak between 12 and $36 \mathrm{~h}$ from beginning of thoracic pain, gradually returning to below the 99th URL value within 5-7 days [1, 3, 40, 76]. On the contrary, in marathon runners an earlier, shorter and lower peak of cTns is usually observed. The shorter peak observed in these cases after physical exercise with respect to those occurring in AMI subjects may depend on the release of cTnI and cTnT from the cytosolic compartment, corresponding to $5 \%-8 \%$ of the total cTn content of cardiomyocytes $[8,75,91]$. It has been suggested that enhanced membrane permeability promoted by the production of reactive oxygen species or alterations in calcium, $\mathrm{pH}$, glucose/fat metabolism, or in communication between integrins, might explain the release of cTn into circulation after strenuous exercise $[25,75]$. Other authors suggest alternative mechanisms: increased cardiovascular stress, inflammation, release of troponin degradation products in "blebs", dehydration, impaired renal clearance, and cTn expression in skeletal muscle [25], although the latter seems to occur only in the case of $\mathrm{cTnT}[92,93]$.

The mechanism underlying the presence of detectable troponin levels in healthy individuals at rest is not yet well understood. cTnI and cTnT may be released due to some physiological mechanisms related to cardiomyocyte renewal in humans [8]. Cardiomyocyte renewal primarily depends on the maturation/proliferation process of endogenous cardiac stem cells, and possibly on bloodborn stem cells [94-97]. It has also been shown that the aging human heart is characterized by a gradual depletion of telocytes, which are in close contact with putative cardiac stem cells and immature cardiomyoblasts, thereby contributing to cardiac renewal [98-102].

Physiological cardiac renewal might help explain not only the variability found in relation to the age of circulating cTnI and cTnT, but also the dependence on gender in healthy subjects. The total number of cardiomyocytes renewed per day might strictly depend on myocardial mass that, in healthy men, is usually greater than in healthy women. Few available experimental data indicate that circulating cTn levels are strictly related to both ventricular mass and gender in large populations of healthy subjects [103-106]. A recent study on 4139 subjects (2099 M and $2040 \mathrm{~F}$, age range 35-74 years) found that several variables, estimated by echocardiography and reflecting cardiovascular phenotypes (including left ventricular mass), were significantly correlated with cTnI concentrations in the general population, and that their distribution differed according to gender and age [105] (Table 3).

\section{Clinical interpretations of 99th URL values}

\section{Are the results of cTn immunoassays biologically equivalent?}

The APACE study [107] recently reported that a diagnosis other than AMI is made in about one out of five AMI

Table 3: Median left ventricular mass (LVM) values (25th-75th percentile, g), estimated by echocardiography, and NT-proBNP (ng/L), both variables divided according to $\mathrm{CTnl}$ concentrations ( $\mathrm{ng} / \mathrm{L}$ ) measured by the high sensitive ARCHITECT method, as reported by Sinning et al. [105].

\begin{tabular}{|c|c|c|c|c|c|}
\hline cTnl concentration & $<1.9 \mathrm{ng} / \mathrm{L}$ & $\geq 1.9-<3.5 \mathrm{ng} / \mathrm{L}$ & $\geq 3.5-<5.2 \mathrm{ng} / \mathrm{L}$ & $\geq 5.2 \mathrm{ng} / \mathrm{L}$ & p-Value ${ }^{a}$ \\
\hline \multicolumn{6}{|l|}{ LVM, g } \\
\hline Women & $120(101,142)$ & $124(106,145)$ & $130(111,154)$ & $135(116,164)$ & 0.0022 \\
\hline Men & $168(143,194)$ & $167(143,191)$ & $175(153,201)$ & $185(158,221)$ & $<0.001$ \\
\hline \multicolumn{6}{|l|}{ NT-proBNP, ng/L } \\
\hline Women & $69(39,114)$ & $69(38,118)$ & $80(45,142)$ & $109(58,235)$ & 0.12 \\
\hline Men & $29(9,52)$ & $26(8,56)$ & $29(10,63)$ & $49(19,130)$ & $<0.001$ \\
\hline Women/men ratio & $523 / 211$ & $665 / 514$ & $509 / 606$ & $343 / 767$ & \\
\hline
\end{tabular}

${ }^{a} p$-Value adjusted for age. 
patients if cTn is measured with another immunoassay (including highly sensitive immunoassays - ARCHITECT for CTnI and ECLIA for CTnT) using the clinical decision (i.e. 99th URL) values suggested by manufacturers [107].

From a methodological viewpoint, the finding that different cTn assays are not biologically equivalent might be explained on the basis of the different biochemical characteristics of cTnI and cTnT [4-6], the systematic differences between cTnI assays [23], and also the fact that various manufacturers use different reference populations to determine 99th URL values $[108,109]$. Samples of AMI patients misdiagnosed in the APACE study [107], are probably those with cTnI and cTnT values around to 99th URL of respective immunoassay methods. These patients may be expected to be at "intermediate" risk (i.e. between the extremely low risk of individuals with cTn values near to the LoD value and the higher risk of individuals with cTn values significantly higher than 99th URL values) [110-113]. Therefore, unsurprisingly, the APACE study reported that patients with misdiagnosis of AMI with two or more cTnI assays were at an intermediate risk, evaluated by Kaplan-Meyer survival curve analysis (i.e. between those with a final diagnosis of unstable angina and those with confirmed diagnosis of AMI) [107].

From the clinical viewpoint, the use of lower clinical decision values for AMI theoretically increases clinical sensitivity, but may also greatly increase the false-positive rate, decreasing the specificity of highly sensitive cTn assay. The 2015 ESC guidelines [32] propose two options for the early ruling-out of AMI using the cTnI and cTnT measurement with highly sensitive methods: (1) a single sample with cTn concentrations below the LoD, and (2) algorithms based on threshold concentrations and/or changed in concentrations measured over $1 \mathrm{~h}$. Furthermore, the cost-effectiveness of diagnostic algorithms based on laboratory tests depends not only on the quality specifications and analytical performances of assay methods, but also on patient population characteristics and healthcare resources [114]. Of particular importance is the evaluation of negative and positive predictive values, as reported in the 2015 ESC guidelines [32] to support the use of algorithms for rapid ruling-out and ruling-in of AMI, which strongly depends on the demographic and clinical characteristics of ED patients [42]. However, the inclusion/exclusion criteria and the demographic and clinical characteristics of ED patient populations vary greatly from study to study [27-29, 104109]. It is therefore not surprising that contradictory results were reported in a recent multicenter study [115] conducted to validate the performance of rapid algorithms for rulingin or ruling-out AMI, as suggested in the 2105 ESC guidelines. The authors concluded that these rapid algorithms could prove useful in identifying patients requiring prompt management, but that they might not be sensitive enough to allow ED physicians to confidently send patients home [115]. Therefore, we believe that clinical decision values, even if recommended by international guidelines, should be considered only indicative, and the effectiveness and efficiency of diagnostic algorithms should always be tested in routine clinical practice.

\section{Are gender-specific cut-offs useful for diagnosis of AMI?}

The guidelines from the Joint ESC/ACCF/AHA/WHF Task Force for the Redefinition of Myocardial Infarction recommend that 99th URL values should be calculated according to gender for the diagnosis of AMI [3]. However, the most recent 2015 ESC guidelines on the management of ACS in patients without persistent ST-segment elevation do not discuss this important issue [32]. Shah et al. [116] recently evaluated the diagnostic accuracy for AMI of the highly sensitive cTnI ARCHITECT assay using gender-specific diagnostic thresholds, as suggested by the manufacturer (M $34 \mathrm{ng} / \mathrm{L}, \mathrm{F} 16 \mathrm{ng} / \mathrm{L}$ ), in 1126 patients (46\% women) with suspected ACS. The highly sensitive cTnI assay actually doubled the diagnoses of type 1 AMI [3] in women (from 11 to $22 \%$; $\mathrm{p}<0.001$ ) with respect to the less sensitive contemporary cTnI assay, but had a lesser effect in men (from 19 to $21 \% ; p=0.002$ ). Furthermore, after a 12-month follow-up, women reclassified as having AMI using the highly sensitive assay with gender specific thresholds $(n=56)$ and those with AMI diagnosed using both methods $(n=56)$ had the highest rate of death or re-infarction compared with women without a diagnosis of AMI $(25 \%, 24 \%$, and $4 \%$, respectively; $\mathrm{p} \leq 0.001)$. These data have prompted debate and research into gender-specific cut-offs for the diagnosis of AMI [117].

Mueller-Hennessen et al. [118] evaluated the impact of age- and gender-specific cut-offs ( $28 \mathrm{ng} / \mathrm{L}$ for $\geq 65$ years; $\mathrm{F}$ $9 \mathrm{ng} / \mathrm{L}, \mathrm{M} 15.5 \mathrm{ng} / \mathrm{L}$ ) for high-sensitivity cTnT compared to the general cut-off for diagnosing AMI in 1282 unselected patients presenting at ED. Age-specific cut-offs led to the prognostic reclassification of patients for 3-month mortality in the entire series, and the ACS cohort $11.8 \%$ and $14.2 \%$ net reclassification improvement, $\mathrm{p}<0.001$, respectively). On the contrary, no significant differences in outcomes could be found using gender-specific cut-offs. Authors concluded that while the influence of gender-specific cTnT cut-offs on diagnostic and prognostic reclassification was only modest in patients with suspected AMI, age-specific cut-offs had a significant impact and could be considered for further validation [118]. 
The results reported by Shah et al. [116] and MuellerHennessen et al. [118] are contradictory concerning the usefulness of using gender-specific cut-off values with highly sensitive methods for cTnI and cTnT. The discrepancies between the results of these two studies may be related to some biological differences between cTnI and cTnT. However, some methodological (related to the experimental protocol and/or the statistical procedure adopted to calculate clinical decision values of study) and analytical (related to analytical sensitivity and specificity of immunoassays) issues may also play a role.

\section{Do differences in troponin-dependent 99th URL values depend on ethnicity?}

The Multi-Ethnic Study of Atherosclerosis (MESA) study evaluated [119] right ventricular volumes and mass by means of cardiac magnetic resonance imaging (MRI) in 4204 subjects, enrolled from a population-based multiethnic sample free of clinical cardiovascular disease. Right ventricular morphology is considered an important predictor of outcome in heart and lung disease. The authors found that age, gender, and ethnic origin were associated with significant differences in right ventricular mass, volumes, and ejection fraction, their results indicating that there are not only gender, but also ethnicity dependent differences in cardiac structure and mass, thus suggesting that turnover of cTn and levels of circulating cTnI and cTnT may be affected by both gender and ethnicity.

Regarding the highly sensitive cTnI assay, results of studies investigating 99th URL values in apparently healthy individuals using the ARCHITECT method are reported in Table 4 [9, 14, 29, 120-126]. These data are from a total of 12,768 (11,237 on excluding those reported by manufacturer) apparently healthy subjects of different ethnicities, including Asian [121, 123, 125], Australian [120], European $[14,29,122,126]$ and North American [9] populations. On considering these studies overall [9, 14, 29, 120-126], median (25th-75th percentiles), the 99th URL values are 19.3 (13.5-23.7) ng/L (M 26.0 [19.6-29.5] ng/L), and (F 11.9 [10.8-18.3] ng/L). However, these studies vary greatly for population size (range, 366-2608), age of participants (age range 18-98 years), inclusion/exclusion criteria (especially in evaluating presence of asymptomatic cardiac disease and co-morbidities - e.g. hypertension, obesity, diabetes mellitus, renal disease), and statistical analysis (parametric or non-parametric) approach for calculating 99th percentile and exclusion of outliers [9, 14, 29, 120-126]. Studies following more rigorous criteria, using both laboratory and clinical data to include/exclude healthy volunteers, tended to report lower 99th URL results for both genders $[29,120]$. Although the data reported in Table 4 are significantly heterogeneous $\left(\mathrm{I}^{2}=99.91 \% ; \mathrm{p} \leq 0.001\right)$, there was a significant difference between the 99th URL values found in men and those in women $(10.97 \mathrm{ng} / \mathrm{L}, \mathrm{SE}=1.979 \mathrm{ng} / \mathrm{L}$, respectively; $p \leq 0.0001$ ). Figure 3 shows a forest plot (calculated using the random effects model) for the 99th URL values reported by the manufacturer and clinical studies for the highly sensitive cTnI method.

Regarding the highly sensitive cTnT ECLIA method, variability among the 99th URL values reported in different studies and by manufacturers is very similar (Table 5) $[9,12,26,41,124,126-128]$. Considering as a whole the clinical studies including a total of 10,078 individuals $[9,12,26$, $47,124,126-128]$, median (25th-75th percentiles) values of 99th URL results of highly sensitive cTnT ECLIA method are for the overall population 14.6 (13.2-18.0) ng/L, for men 16.0 (15.0-19.5) ng/L, and for women 12.0 (9.6-12.5) ng/L, respectively. The results reported by Gaggin et al. [128], including data related to two different populations (i.e. North American and Vietnamese cohorts) are intriguing: the 99th URL value in the Vietnamese women was higher than the respective value in men (i.e. $25 \mathrm{ng} / \mathrm{L}$ vs. $19 \mathrm{ng} / \mathrm{L}$ ) (Table 5). However, the Authors reported that, as expected, in the Vietnamese cohort the median (95\% CI) cTnT concentrations in men (4.0 [3.0-5.0] ng/L) were higher than in women $(2.5$ [2.5-4.09] ng/L). These data [128] suggest that the higher 99th URL value in Vietnamese women was probably due to outlier values not corrected at statistical analysis. Although data reported in Table 4 are significantly heterogeneous $\left(\mathrm{I}^{2}=99.93 \% ; \mathrm{p}<0.001\right)$, there was also a significant difference between the 99th URL values in men and women for the 99th URL value of cTnT measured using the highly sensitive ECLIA method ( $4.59 \mathrm{ng} / \mathrm{L}, \mathrm{SE}=1.5232 \mathrm{ng} / \mathrm{L} ; \mathrm{p}=0.0026)$. Figure 4 shows a forest plot based on the random effects model for the 99th URL values reported by manufacturer and clinical studies for the highly sensitive cTnT method. Data reported in Tables 4 and 5, and Figures 3 and 4, confirm that genderdifferences in 99th URL values are present for both cTnI and cTnT. In particular, on average the gender-difference between the mean 99th URL values is two-fold greater for cTnI than cTnT (i.e. $10.97 \mathrm{ng} / \mathrm{L}$ vs. $4.59 \mathrm{ng} / \mathrm{L}$ ).

Given that cTnI has a lower molecular mass than cTnT (about 22,000 vs. $37,000 \mathrm{Da}$ ) [129], the results reported in various studies $[9,12,26,47,120,122-124]$ indicate that there is a larger number of circulating cTnI-related molecules than cTnT-related molecules in healthy subjects. Furthermore, since cTnI and cTnT are present in the sarcomeric complex in a molecular ratio of 1:1, these differences between the circulating cTns are probably related to differences in 
Table 4: Values of 99th percentile URL measured by the hs-cTnI method using the ARCHITECT platform in apparently healthy adult subjects, according to literature and manufacturer data.

\begin{tabular}{|c|c|c|c|c|c|}
\hline Gender & Number of subjects & Age range, years & 99th URL, ng/L & $95 \% \mathrm{Cl}$ range, $\mathrm{ng} / \mathrm{L}$ & Reference \\
\hline Men & 766 & - & 34.2 & $28.9-39.2$ & Manufacturer \\
\hline Women & 765 & - & 15.6 & $13.8-17.5$ & \\
\hline Overall & 1531 & $21-75$ & 26.2 & $23.3-29.7$ & \\
\hline Men & 273 & $19-62$ & 36 & - & Apple et al. [9] \\
\hline Women & 252 & $18-64$ & 15 & - & \\
\hline Overall & 525 & $18-64$ & 23 & $16-63^{a}$ & \\
\hline Men & 776 & - & 27.0 & $20-67$ & Krintus et al. [14] \\
\hline Women & 993 & - & 11.4 & $10-15$ & \\
\hline Overall & 1769 & $19-91$ & 19.3 & $14-25$ & \\
\hline Men & 1292 & - & 28.4 & $20.5-42.1$ & Zeller et al. [29] \\
\hline Women & 1316 & - & 12.4 & $9.0-20.9$ & \\
\hline Overall & 2608 & $35-74$ & 21.3 & $17.5-29.2$ & \\
\hline Men & 246 & - & 14.9 & - & Koerbin et al. [120] \\
\hline Women & 318 & - & 11.1 & - & \\
\hline Overall & 564 & $48-95$ & 13.6 & $13.2-14.6^{\mathrm{a}}$ & \\
\hline Men & 597 & $35-65$ & 32.7 & $21.1-47.9^{\mathrm{a}}$ & Aw et al. [121] \\
\hline Women & 523 & $40-65$ & 17.9 & $10.7-26.3^{a}$ & \\
\hline Overall & 1120 & $35-65$ & 25.6 & $19.6-32.6^{a}$ & \\
\hline Men & 171 & - & 18.3 & - & Collinson et al. [122] \\
\hline Women & 195 & - & 9.5 & - & \\
\hline Overall & 366 & $45-89$ & 12.3 & $6.2-21.0$ & \\
\hline Men & 349 & - & 25.0 & $12.4-30.6^{\mathrm{a}}$ & Lee et al. [123] \\
\hline Women & 195 & - & 19.3 & - & \\
\hline Overall & 544 & $20-71$ & 19.3 & $13.3-28.6^{a}$ & \\
\hline Men & 729 & - & 20 & $14-22$ & Kimenai et al. [124] \\
\hline Women & 806 & - & 11 & $8-13$ & \\
\hline Overall & 1535 & $40-75$ & 13 & $11-18$ & \\
\hline Men & 426 & $24-87$ & 20 & $15-69^{a}$ & Ji et al. [125] \\
\hline Women & 428 & $18-90$ & 19 & $11-41^{\mathrm{a}}$ & \\
\hline Overall & 854 & $18-90$ & 18 & $14-35^{a}$ & \\
\hline Men & 826 & - & 27.5 & $21.4-31.3^{\mathrm{a}}$ & Ungerer et al. [126] \\
\hline Women & 526 & - & 21.5 & $21.5-101.5^{\mathrm{a}}$ & \\
\hline Overall & 1352 & $<50$ & 25.7 & $19.2-30.5^{\mathrm{a}}$ & \\
\hline
\end{tabular}

${ }^{\mathrm{a}} \mathrm{Cl} 90 \%$.

intra- [130] or extra-cellular [131-133] catabolism and the peripheral turnover of cTnI and cTnT. A recent study [134] found that circulating levels of cTnT, unlike cTnI, have a diurnal rhythm, thus bearing out the hypothesis that there are some differences in the release from cardiomyocytes and/or peripheral turnover between cTnI and cTnT.

\section{Clinical relevance of gender-specific decision values for $\mathrm{cTnl}$ and $\mathrm{cTnT}$ assay}

From a clinical point of view, a fundamental question is whether the use of gender-specific cutoff values for highly sensitive cTnI and/or cTnT assays actually allows a more accurate detection of patients with non-ST-segment elevation acute coronary syndromes (NSTEMI-ACS), who are at higher risk of presenting major cardiovascular events in the short term. Regarding the highly sensitive cTnI assay, some studies report that the use of gender specific decision values significantly increases AMI diagnosis especially in women, with better stratification of risk [112, 135-137], while another study found contradictory results [138]. The evidences regarding the highly sensitive cTnT assay are, on the contrary, all negative, suggesting that genderspecific clinical decision values are not particularly useful for the highly sensitive cTnT assay [117, 118, 139]. These 


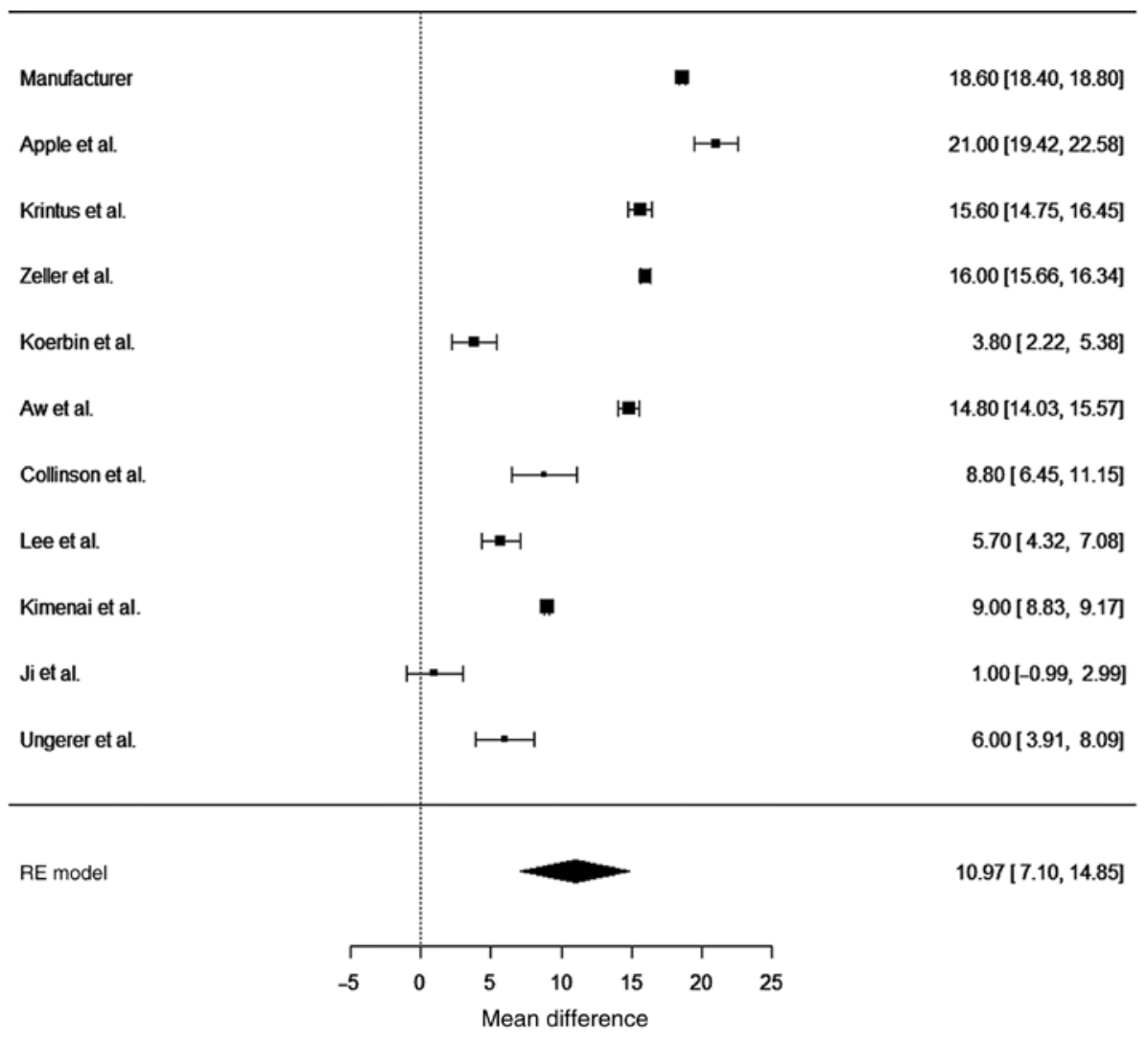

Figure 3: Forest plot showing the differences [CI 95\%] between 99th URL values reported by manufacturer and clinical studies for the highly sensitive CTnI ARCHITECT method in men and women.

differences between cTns are in part expected considering the lower gender-dependence of cTnT (Table 5) compared to $\mathrm{cTnI}$ (Table 4) values.

As discussed in detail above, cTnI and cTntT levels in healthy adults might depend strongly on the physiological turnover of cardiomyocytes, and therefore on the cardiac mass, which is on average greater in men than in women. If so, a very close correlation would be found between the ventricular mass and circulating $\mathrm{cTnI}$ and $\mathrm{cTnT}$ levels. However, a straightforward, economical method for accurately estimating left ventricular mass (LVM) in a large population of healthy adults is currently unavailable. Echocardiographic evaluation is usually recommended for assessing LVM in large population studies and in routine clinical practice when cardiovascular risk assessment is made in asymptomatic adults [140]. A recent study [105] reported that LVM values, estimated by echocardiography, are significantly correlated with $\mathrm{cTnI}$ concentrations in the general population, the distribution, different in men and women, being influenced by age. Although on average men present higher values than women for CTnI and LVM than women, the same cTnI concentrations are present with similar frequency in women and men with great variations in LVM values, especially for concentrations ranging from $1.9 \mathrm{ng} / \mathrm{L}$ to $5.2 \mathrm{ng} / \mathrm{L}$, which cover the majority of the population (2294/4139 subjects; 55\%) [105]. It is not yet known whether this overlapping is due to true differences between women and men for cardiac structure and/or troponin content, or to some limitations (including performance resolution) in echocardiographic methodology [141, 142]. In healthy individuals, echocardiography systematically shows smaller atrial and ventricular dimensions and volumes, and larger wall thickness and mass, then cardiac MRI [141]. Although cardiac MRI is considered more accurate than echocardiography in the estimation of cardiac LVM, no data are available on the correlations between cardiac mass values measured by cardiac MRI and circulating levels of cTnI and cTnT measured with highly sensitive methods in large populations of healthy adults.

From both the pathophysiological and clinical viewpoint, it is interesting to compare the circulating levels of natriuretic peptides and cTns reported in the study by Sinning et al. [105]. Table 3 reports NT-proBNP values, subdivided according to cTnI values. These data [105] confirm that circulating levels of natriuretic peptides are strongly gender-dependent, values in women of fertile age being higher than in age-matched men. Interestingly, only in men were cTnI values significantly associated with NT-proBNP 
Table 5: Values of 99th percentile URL measured by the ECLIA hs-cTnT method in apparently healthy adult subjects, according to literature and manufacturer data.

\begin{tabular}{|c|c|c|c|c|c|}
\hline Gender & Number of subjects & Age range, years & 99th URL, ng/L & $95 \% \mathrm{Cl}$ range, $\mathrm{ng} / \mathrm{L}$ & Reference \\
\hline Overall & 533 & $21-71$ & 14 & $12.7-24.9$ & Manufacturer \\
\hline Men & 273 & $19-62$ & 20 & - & Apple et al. [9] \\
\hline Women & 252 & $18-64$ & 13 & - & \\
\hline Overall & 525 & $18-64$ & 15 & $13-21^{a}$ & \\
\hline Men & 268 & - & 15.5 & - & Saenger et al. [12] \\
\hline Women & 265 & - & 8.9 & - & \\
\hline Overall & 533 & $20-71$ & 14.2 & - & \\
\hline Men & 503 & $20-64$ & 13.1 & $11.9-13.4$ & Franzini et al. [26] \\
\hline Women & 369 & $20-64$ & 9.6 & $8.4-13.8$ & \\
\hline Overall & 872 & $20-64$ & 12.4 & $11.5-13.2$ & \\
\hline Men & 1346 & $30-64$ & 23 & $19-47$ & Gore et al. [41] \\
\hline Women & 1609 & $30-64$ & 12 & $9-18$ & \\
\hline Overall & 2955 & $30-64$ & 18 & $16-23$ & \\
\hline Men & 729 & - & 16 & $15-17$ & Kimenai et al. [124] \\
\hline Women & 806 & - & 12 & $10-14$ & \\
\hline Overall & 1535 & $40-75$ & 15 & $13-16$ & \\
\hline Men & 826 & $<50$ & 15.8 & $12.7-20.4^{\mathrm{a}}$ & Ungerer et al. [126] \\
\hline Women & 526 & $<50$ & 9.6 & $6.8-13.5^{\mathrm{a}}$ & \\
\hline Overall & 1352 & $<50$ & 14.0 & $10.8-17.7^{\mathrm{a}}$ & \\
\hline Men & 309 & - & 14.5 & & Giannitsis et al. [127] \\
\hline Women & 307 & - & 10.0 & & \\
\hline Overall & 616 & $20-71$ & 13.5 & & \\
\hline Men & 253 & & 16.5 & & Gaggin et al. [128] \\
\hline Women & 312 & & 12.0 & & US cohort \\
\hline Overall & 565 & $41.4(13.4)^{\mathrm{b}}$ & 15.1 & & \\
\hline Men & 300 & & 19 & & Gaggin et al. [128] \\
\hline Women & 292 & & 25 & & Vietnamese cohort \\
\hline Overall & 592 & $41.0(14.8)^{\mathrm{b}}$ & 19 & & \\
\hline
\end{tabular}

${ }^{\mathrm{a}} \mathrm{Cl} 90 \%$. ${ }^{\mathrm{b}}$ Mean (SD).

(the statistical significance found is probably due only to the group with $c \operatorname{TnI}>5.2 \mathrm{ng} / \mathrm{L}$ ). These data suggest that cardiac structural and functional changes (probably related to co-morbidities such as hypertension, diabetes and renal dysfunction), mirrored by increased NT-proBNP concentration, are present in some asymptomatic volunteers of both genders with higher cTnI concentrations ( $>5.2 \mathrm{ng} / \mathrm{L})$ [143].

From a clinical viewpoint, these data confirm that natriuretic peptides and cTns provide robust additional/ adjunctive/ clinical information. Accordingly, these biomarkers should be always measured together in patients with asymptomatic cardiac disease for risk stratification. From a pathophysiological viewpoint, it is important to note that the opposite actions of male and female gendersteroid hormones may explain the difference in circulating levels of natriuretic peptides and cTn. Indeed, male steroid hormones may have an anabolic effects on cardiac cells (inducing cardiac hypertrophy) [144], but also an inhibitory action on the production of cardiac natriuretic hormones [145, 146]; female gender steroid hormones may have anti-proliferative effects on myocardiocytes [144], but stimulate the production/secretion of cardiac natriuretic peptides $[145,146]$.

Several recent studies have demonstrated the association between the risk of major cardiovascular events and detectable, presumably still normal, cTn values measured with highly sensitive cTnI and cTnT assays [110-113, 147]. These studies give rise to the question of whether there is a myocardial injury threshold beyond which individual risk increases thus being of potential clinical utility in cardiovascular risk prediction. However, evidence from the same studies supports the hypothesis that the risk of cardiovascular increases continuously and progressively as from the limit of detection of cTn immunoassays. From a statistical 


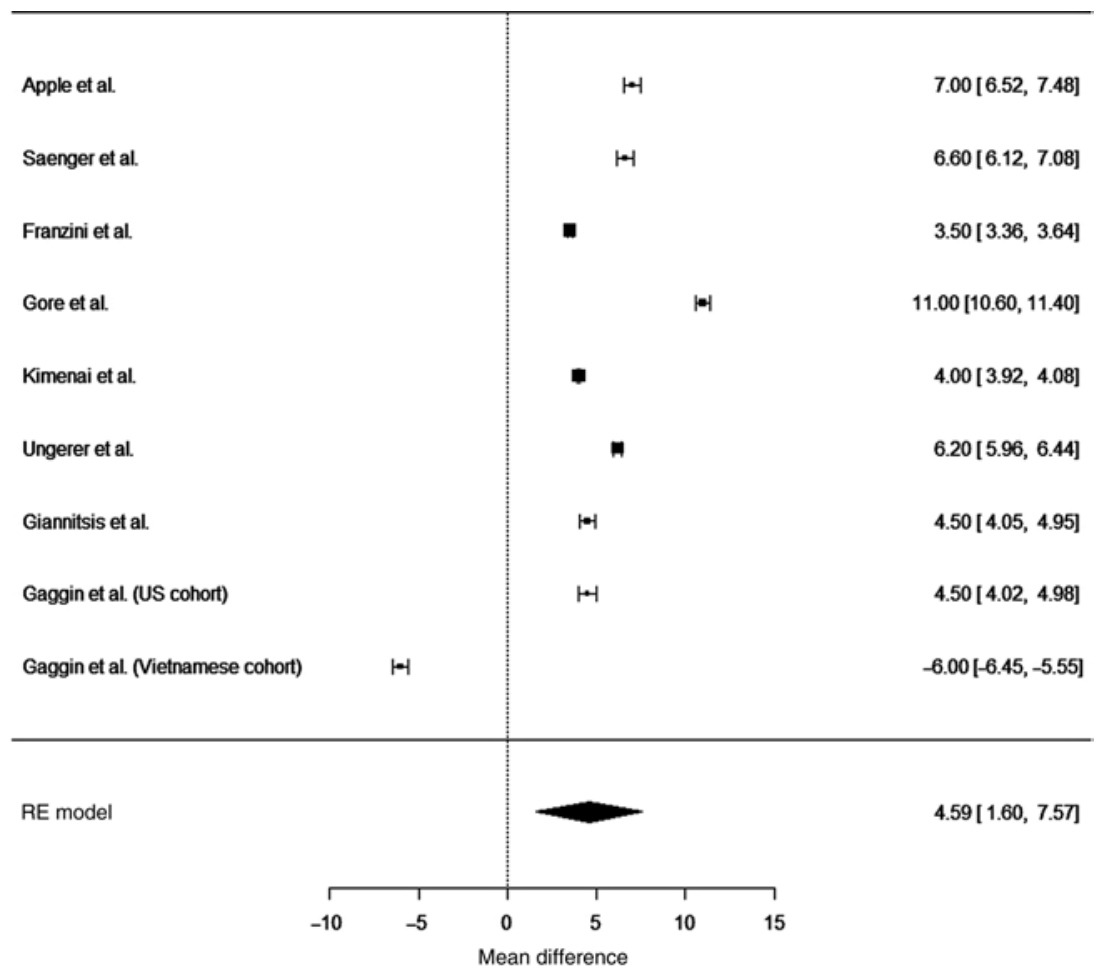

Figure 4: Forest plot showing the differences [CI 95\%] between 99th URL values reported by manufacturer and clinical studies for the highly sensitive CTnT ECLIA method in men and women.

viewpoint, when using of decision values (e.g. 99th URL) it may be inadvisable to dichotomize continuous variables for multiple regression analyses, because this approach can significantly reduce information [148]. Therefore, the 99th URL should be used with caution in view of the risk of false positives and negatives. Clinical input is of utmost importance in minimizing this risk. Further studies are needed to evaluate whether a cut-off values for highly sensitive cTnI and cTnT assay may be effective for cardiovascular risk prediction in clinical practice.

\section{Future perspectives}

Our critical review of data in the literature supports the observations by Sandoval and Apple [17], who reported that no uniform procedure is followed, and that no uniform guidelines have been issued by experts or regulatory bodies to ensure that researchers or manufacturers of cTn assays are guided in "their quest to define normality". Nor is adequate attention paid to the approach for selecting a "normal" reference population and the criteria to use for calculating the 99th URL value for cTn assays. Indeed, recent studies have demonstrated the importance of the statistical manipulation of data in determining the 99th URL values, in particular regarding the use of more robust statistical methods [26, 27, 49]. Moreover, some authors suggest the clinical relevance of determining 99th URL values using the popular cTnI and cTnT immunoassays on the same very large reference population in order to better evaluate and accurately compare the differences among methods [9]. We therefore believe that international recommendations are urgently needed, not only for demographic and physiological variables and the criteria for the definition of the healthy reference population, but also for mathematical algorithms enabling the calculation of clinical decision values. According to Sandoval and Apple [17], these guidelines should be established by an expert consensus group consisting of laboratory and clinical scientists, biomedical statisticians and industry and regulatory representatives.

Until the necessary guidelines have been developed, clinicians and clinical chemists should follow some minimal criteria for the more accurate screening of presumably normal individuals, who have a negative clinical history for cardiovascular disease, other chronic disease, or continuous use of such medication. Moreover, some surrogate biomarkers may prove useful for ruling out the presence of asymptomatic cardiac disease, such as natriuretic peptides, as well as some non-invasive cardiac investigations, such as ECG and echocardiography and carotid ultrasound [17, 26, 149-151]. Other standard laboratory tests may be useful in ruling out the presence of 
renal dysfunction, anemia, diabetes mellitus, or hepatic diseases. As far as the demographic characteristics of reference population are concerned, a minimum of 300 men and 300 women are required, including several ethnic population groups, and diverse age distribution (e.g. from 18 to 70 years) [17, 30, 31].

Acknowledgments: The authors would like to thank Claudio Galli, MD, PhD, Associate Director, Medical Scientific Liaison Europe, Abbott Diagnostics, and Dr. Daniela Bellavista, Medical Project Manager, Medical \& Market Access, Roche Diagnostics, for their information about the analytical characteristics of highly sensitive cTnI and cTnT assays.

Author contributions: All the authors have accepted responsibility for the entire content of this submitted manuscript and approved submission.

Research funding: None declared.

Employment or leadership: None declared.

Honorarium: None declared.

Competing interests: The funding organization(s) played no role in the study design; in the collection, analysis, and interpretation of data; in the writing of the report; or in the decision to submit the report for publication.

\section{References}

1. Alpert JS, Thygesen K, Antman E, Bassand JP. Myocardial infarction redefined: a consensus document of the Joint European Society of Cardiology/American College of Cardiology Committee for the redefinition of myocardial infarction. J Am Coll Cardiol 2000;36:959-69.

2. Thygesen K, Alpert JS, White HD. Joint ESC/ACCF/AHA/WHF Task Force for the Redefinition of Myocardial Infarction. Universal definition of myocardial infarction. J Am Coll Cardiol 2007;50:2173-95.

3. Thygesen K, Alpert JS, Jaffe AS, Simoons ML, Chaitman BR, White HD. Joint ESC/ACCF/AHA/WHF Task Force for Universal Definition of Myocardial. Third universal definition of myocardial infarction. J Am Coll Cardiol 2012;60:1581-98.

4. Morrow DA, Cannon CP, Jesse RL, Newby LK, Ravkilde J, Storrow $A B$, et al. National Academy of Clinical Biochemistry Laboratory Medicine Practice Guidelines: clinical characteristics and utilization of biochemical markers in acute coronary syndromes. Clin Chem 2007;53:552-74.

5. Panteghini M, Pagani F, Yeo KT, Apple FS, Christenson RH, Dati $\mathrm{F}$, et al. Evaluation of imprecision for cardiac troponin assays at low-range concentrations. Clin Chem 2004;50:327-32.

6. Apple FS, Jesse RL, Newby LK, Wu AH, Christenson RH, Cannon CP, et al. National Academy of Clinical Biochemistry and IFCC Committee for Standardization of Markers of Cardiac Damage Laboratory Medicine Practice Guidelines: analytical issues for biochemical markers of acute coronary syndromes. Clin Chem 2007;53:547-51.
7. Clerico A, Fortunato A, Ripoli A, Prontera C, Zucchelli GC, Emdin $M$. Distribution of plasma cardiac troponin I values in healthy subjects: pathophysiological considerations. Clin Chem Lab Med 2008;46: 804-8.

8. Giannoni A, Giovannini S, Clerico A. Measurement of circulating concentrations of cardiac troponin I and $\mathrm{T}$ in healthy subjects: a tool for monitoring myocardial tissue renewal? Clin Chem Lab Med 2009;47:1167-77.

9. Apple FS, Ler R, Murakami MM. Determination of 19 cardiac troponin I and T assay 99th percentile values from a common presumably healthy population. Clin Chem 2012;58:1574-81.

10. Prontera C, Fortunato A, Storti S, Mercuri A, Longombardo G, Zucchelli GC, et al. Evaluation of analytical performance of the Siemens ADVIA TnI Ultra Immunoassay. Clin Chem 2007;53:1722-3.

11. Jarausch J, Braun S, Dolci A, Jaffe A, Muhlbacher A, Olven C, et al. Evaluation of a development version of the Elecsys highly sensitive troponin T assay. Clin Chem 2008;54(Suppl 6):A91.

12. Saenger AK, Beyrau R, Braun S, Cooray R, Dolci A, Freidank $\mathrm{H}$, et al. Multicentre analytical evaluation of a high-sensitive troponin T assay. Clin Chim Acta 2011;412:748-54.

13. Venge $P$, James $S$, Jansson L, Lindahl B. Clinical performance of two highly sensitive cardiac troponin I assays. Clin Chem 2009;55:109-16.

14. Krintus M, Kozinski M, Boudry P, Capell NE, Köller U, Lackner K, et al. European multicenter analytical evaluation of the Abbott ARCHITECT STAT highly sensitive troponin I immunoassay. Clin. Chem Lab Med 2014;52:1657-65.

15. Caselli C, Cangemi G, Masotti S, Ragusa R, Gennai I, Del Ry $S$, et al. Plasma cardiac troponin I concentrations in healthy neonates, children and adolescents measured with a highly sensitive immunoassay method: Highly sensitive troponin I in pediatric age. Clin Chim Acta 2016;458:68-71.

16. Casagranda I, Cavazza M, Clerico A, Galvani M, Ottani F, Zaninotto $M$, et al. Proposal for the use in emergency departments of cardiac troponins measured with the latest generation methods in patients with suspected ACSwithout persistent ST-segment elevation. Clin Chem Lab Med 2013;51:1727-37.

17. Sandoval Y, Apple FS. The global need to define normality: the 99th percentile value of cardiac troponin. Clin Chem 2014;60:455-62.

18. Apple FS, Collinson PO. IFCC Task Force on Clinical Applications of Cardiac Biomarkers. Analytical characteristics of high-sensitivity cardiac troponin assays. Clin Chem 2012;58:54-61.

19. Sader WA. Imprecision profiling. Clin Biochem Rev 2008;29(Suppl 1):S33-6.

20. CLSI EP17-A protocol. Protocols for determination of limits of detection and limits of quantitation; approved guidelines. 2004, Vol. 24, No. 34. Wayne, Pennsylvania.

21. CLSI EP21 protocol. Evaluation o ftotal analytical error for quantitative medical laboratory measurement procedure, 2nd ed. Wayne Pennsylvania, 2016.

22. Spencer CA, Takeuchi M, Kazarosyan M. Current status and performance goals for serum thyrotropin (TSH) assays. Clin Chem 1996;42:140-5.

23. Clerico A, Ripoli A, Masotti S, Prontera C, Chiappino D, Della Latta $D$, et al. Pilot study on harmonization of cardiac troponin I immunoassays using patients and quality control plasma samples. On behalf of the Italian Section of the European Ligand Assay Society (ELAS) and of the Study Group on Cardiovascular 
Biomarkers of the Società Italiana di Biochimica Clinica (SIBioC). Clin Chem Acta 2016;456:42-8.

24. Tate JT, Bunk D, Christenson RH, Barth JH, Katrukha A, Noble JE, et al. Valuation of standardization capability of current cardiac troponin I assays by a correlation study: results of an IFCC pilot project. Clin Chem Lab Med 2015;53:677-90.

25. Gresslien T, Agewall S. Troponin and exercise. Int J Cardiol 2016;221:609-21.

26. Franzini M, Lorenzoni V, Masotti S, Prontera C, Chiappino D, Latta DD, et al. The calculation of the cardiac troponin T 99th percentile of the reference population is affected by age, gender, and population selection: a multicenter study in Italy. Clin Chim Acta 2015;438:376-81.

27. Eggers KM, Lind L, Venge P, Lindhal B. Factors influencing the 99th percentile of cardiac troponin I evaluated in communitydwelling individuals at 70 and 75 years of age. Clin Chem 2013;59:1068-73.

28. Keller T, Ojeda F, Zeller T, Wild PS, Tzikas S, Sinning CR, et al. Defining a reference population to determine the 99th percentile of a contemporary sensitive cardiac troponin I assay. Int J Cardiol 2013;167:1423-9.

29. Zeller T, Ojeda F, Brunner FJ, Peitsmeyer P, Münzel T, Binder H, et al. High-sensitivity cardiac troponin I in the general population - defining reference populations for the determination of the 99th percentile in the Gutenberg Health Study. Clin Chem Lab Med 2015;53:699-706.

30. Thygesen K, Mair J, Katus H, Plebani M, Venge P, Collinson P, et al. Recommendations for the use of cardiac troponin measurement in acute cardiac care. Eur Heart J 2010;31:2197-204.

31. Hickman PE, Badrick T, Wilson SR, McGill D. Reporting of cardiac troponin problems with the 99th population percentile. Clin Chim Acta 2007;381:182-3.

32. Roffi M, Patrono C, Collet JP, Mueller C, Valgimigli M, Andreotti F, et al. 2015 ESC Guidelines for the management of acute coronary syndromes in patients presenting without persistent ST-segment elevation: Task Force for the Management of Acute Coronary Syndromes in Patients Presenting without Persistent ST-Segment Elevation of the European Society of Cardiology (ESC). Eur Heart J 2016;37:267-315.

33. Koerbin G, Potter JM, Abhayaratna WP, Telford RD, Badrick T, Apple FS, al. Longitudinal studies of cardiac troponin I in a large cohort of healthy children. Clin Chem 2012;58:1665-72.

34. Koerbin G, Potter JM, Abhayaratna WP, Telford RD, Hickman PE. The distribution of cardiac troponin I in a population of healthy children: lessons for adults. Clin Chim Acta 2013;417:54-6.

35. Kuster N, Monnier K, Baptista G, Dupuy AM, Badiou S, Bargnoux AS, et al. Estimation of age- and comorbidities-adjusted percentiles of high-sensitivity cardiac troponin T levels in the elderly. Clin Chem Lab Med 2015;53:691-8.

36. Hammarsten O, Fu ML, Sigurjonsdottir R, Petzold M, Said L, Landin-Wilhelmsen $\mathrm{K}$, et al. Troponin T percentiles from a random population sample, emergency room patients and patients with myocardial infarction. Clin Chem 2012;58:628-37.

37. Xu R, Ye P, Luo L, Sheng L, Wu H, Xiao W, et al. Association between high-sensitivity cardiac troponin $\mathrm{T}$ and $\mathrm{N}$-terminal probrain natriuretic peptide in a community based population. Chin Med J (Engl) 2014;127:638-44.

38. Thygesen K, Mair J, Giannitsis E, Mueller C, Lindahl B, Blankenberg $\mathrm{S}$, et al. How to use high-sensitivity cardiac troponins in acute cardiac care. Eur Heart J 2012;33:2252-7.
39. Rosengren A, Wallentin L, Simoons M, Gitt AK, Behar S, Battler $A$, et al. Age, clinical presentation, and outcome of acute coronary syndromes in the Euroheart ACSsurvey. Eur Heart J 2006;27:789-95.

40. Giannitsis E, Katus HA. Cardiac troponin level elevations not related to acute coronary syndromes. Nat Rev Cardiol 2013;10:623-34.

41. Gore MO, Seliger SL, Defilippi CR, Nambi V, Christenson RH, Hashim IA, et al. Age- and gender-dependent upper reference limits for the high-sensitivity cardiac troponin T assay. J Am Coll Cardiol 2014;63:1441-8.

42. Sackett DL, Haynes RB. Evidence base of clinical diagnosis. The architecture of diagnosis research. Br Med J 2002;324:539-41.

43. Dhalla NS, Rangi S, Babick AP, Zieroth S, Elimban V. Cardiac remodeling and subcellular defects in heart failure due to myocardial infarction and aging. Heart Fail Rev 2012;17:671-81.

44. Lakatta EG. So! What's aging? Is cardiovascular aging a disease? J Mol Cell Cardiol 2015;83:1-13.

45. Diris JH, Hackeng CM, Kooman JP, Pinto YM, Hermens WT, van Dieijen-Visser MP. Impaired renal clearance explains elevated troponin T fragments in hemodialysis patients. Circulation 2004;109:23-5.

46. Parikh RH, Seliger SL, deFilippi CR. Use and interpretation of high sensitivity cardiac troponins in patients with chronic kidney disease with and without acute myocardial infarction. Clin Biochem 2015;48:247-53.

47. Eggers KM, Jaffe AS, Lind L, Venge P, Lindahl B. Value of cardiac troponin I cutoff concentrations below the 99th percentile for clinical decision-making. Clin Chem 2009;55:85-92.

48. Mingels A, Jacobs L, Michielsen E, Swaanenburg J, Wodzig W, van Dieijen-Visser M. Reference population and marathon runner sera assessed by highly sensitive cardiac troponin $T$ and commercial cardiac troponin T and I assays. Clin Chem 2009;55:101-8.

49. Krintus M, Kozinski M, Boudry P, Lackner K, Lefèvre G, Lennartz $L$, et al. Defining normality in a European multinational cohort: Critical factors influencing the 99th percentile upper reference limit for high sensitivity cardiac troponin I. Int J Cardiol 2015;187:256-63.

50. Caselli C, Ragusa R, Prontera C, Cabiati M, Cantinotti M, Federico G, et al. Distribution of circulating cardiac biomarkers in healthy children: from birth through adulthood. Biomark Med 2016;10:357-65.

51. Krintus M, Kozinski M, Mayasiak S, Nowak-Los L, Lennartz L, Shih J, et al. ARCHITECT STAT Highly sensitive Troponin I Familiarization Study (FAM) in the Department of Laboratory Medicine, Collegium Medicum, Nicolaus Copernicus University in Bydgoszcz, Poland. Folia Med Copernicana 2015;3:107-12.

52. Middleton N, George K, Whyte G, Gaze D, Collinson P, Shave R. Cardiac troponin $T$ release is stimulated by endurance exercise in healthy humans. J Am Coll Cardiol 2008;52:1813-4.

53. Giannitsis E, Roth HJ, Leithauser RM, Scherhag J, Beneke R, Katus HA. New highly sensitivity assay used to measure cardiac troponin T concentration changes during a continuous $216-\mathrm{km}$ marathon. Clin Chem 2009;55:590-2.

54. Mingels A, Jacobs L, Michielsen E, Swaanenburg J, Wodzig W, van Dieijen-Visser M. Reference population and marathon runner sera assessed by highly sensitive cardiac troponin $T$ and commercial cardiac troponin T and I assays. Clin Chem 2009;55:101-8. 
55. Saravia SG, Knebel F, Schroeckh S, Ziebig R, Lun A, Weimann A, et al. Cardiac troponin T release and inflammation demonstrated in marathon runners, Clin Lab 2010;56:51-8.

56. Scherr J, Braun S, Schuster T, Hartmann C, Moehlenkamp S, Wolfarth B, et al. 72-h kinetics of high-sensitive troponin T and inflammatory markers after marathon. Med Sci Sports Exerc 2011;43:1819-27.

57. Passino C, Severino S, Poletti R, Piepoli MF, Mammini C, Clerico $A$, et al. Aerobic training decrease B-type natriuretic peptide expression and adrenergic activation in patients with heart failure. J Am Coll Cardiol 2006;47:1835-9.

58. Passino C, Poletti R, Bramanti F, Prontera C, Clerico A, Emdin M. Neuro-hormonal activation predicts ventilatory response to exercise and functional capacity in patients with heart failure. Eur J Heart Fail 2006;8:46-53.

59. Pastormerlo LE, Agazio A, Benelli E, Gabutti A, Poletti R, Prontera $C$, et al. Usefulness of high-sensitive troponin elevation after effort stress to unveil vulnerable myocardium in patients with heart failure. Am J Cardiol 2015;116:567-72.

60. Wu AH. Analytical validation of novel cardiac biomarkers used in clinical trials. Am Heart J 2015;169:674-83.

61. Keller T, Zeller T, Ojeda F, Tzikas S, Lillpopp L, Sinning C, et al. Serial changes in highly sensitive troponin I assay and early diagnosis of myocardial infarction. J Am Med Assoc 2011;306:2684-93.

62. Simpson AJ, Potter JM, Koerbin G, Oakman C, Cullen L, Wilkes $\mathrm{G}$, et al. Use of observed within-person variation of cardiac troponin in emergency department patients for determination of biological variation and percentage and absolute reference change values. Clin Chem 2014;60:848-54.

63. Collinson PO, Heung YM, Gaze D, Boa F, Senior R, Christenson $\mathrm{R}$, et al. Influence of population selection on the 99th percentile reference value for cardiac troponin assays. Clin Chem 2012;58:219-25.

64. Hickman PE, Lindahl B, Cullen L, Koerbin G, Tate J, Potter JM. Decision limits and the reporting of cardiac troponin: Meeting the needs of both the cardiologist and the ED physician. Crit Rev Clin Lab Sci 2015;52:28-44.

65. Eggers KM, Apple FS, Lind L, Lindahl B. The applied statistical approach highly influences the 99th percentile of cardiac troponin I. Clin Biochem 2016;49:1109-12.

66. Clinical Laboratory Standards Institute, Defining, Establishing and Verifying Reference Intervals in the Clinical Laboratory; Approved Guideline, 3rd ed. CLSI Document EP28-A3c, CLSI, Wayne (PA), 2008.

67. Reed AH, Henry RJ, Mason WB. Influence of statistical method used on the resulting estimate of normal range. Clin Chem 1971;17:275-84.

68. Harrell F, Davis CE. A new distribution-free quantile estimator. Biometrika 1982;69:635-40.

69. Dixon WJ. Processing data for outliers. Biometrics 1983;9:74-89.

70. Michielsen EC, Bisschops PG, Janssen MJ. False positive troponin result caused by a true macrotroponin. Clin Chem Lab Med 2011;49:923-5.

71. Warner JV, Marshall GA. High incidence of macrotroponin I with a high-sensitivity troponin I assay. Clin Chem Lab Med 2016;54:1821-9.

72. Lippi G, Aloe R, Meschi T, Borghi L, Cervellin G. Interference from heterophilic antibodies in troponin testing. Case report and systematic review of the literature. Clin Chim Acta 2013;426:79-84.
73. Savukoski T, Engström E, Engblom J, Ristiniemi N, Wittfooth S, Lindahl B, et al. Troponin-specific autoantibody interference in different cardiac troponin I assay configurations. Clin Chem 2012;58:1040-8.

74. Kelley WE, Januzzi JL, Christenson RH. Increases of cardiac troponin in conditions other than ACSand heart failure. Clin Chem 2009;55:2098-112.

75. Hickman PE, Potter JM, Aroney C, Koerbin G, Southcott $\mathrm{E}, \mathrm{Wu} \mathrm{AH}$, et al. Cardiac troponin may be released by ischemia alone, without necrosis. Clin Chim Acta 2010;411:318-23.

76. Wu AH, Apple FS, Gibler WB, Jesse RL, Warshaw MM, Valdes R Jr. National Academy of Clinical Biochemistry Standards of Laboratory Practice: recommendations for the use of cardiac markers in coronary artery diseases. Clin Chem 1999;45:1104-21.

77. Klinkenberg LJ, Luyten P, van der Linden N, Urgel K, Snijders DP, Knackstedt C, et al. Cardiac troponin T and I release after a 30-km run. Am J Cardiol 2016;118:281-7.

78. Shave R, Ross P, Low D, George K, Gaze D. Cardiac troponin I is released following high-intensity short-duration exercise in healthy humans. Int J Cardiol 2010;145:337-9.

79. Nie J, Tong TK, Shi Q, Lin H, Zhao J, Tian Y. Serum cardiac troponin response in adolescents playing basketball. Int J Sports Med 2008;29:449-52.

80. Ma G, Liu Y, Liu K. Influence of repeated bouts of table tennis training on cardiac biomarkers in children. Pediatr Cardiol 2014;35:711-8.

81. Fu F, Nie J, Tong TK. Serum cardiac troponin T in adolescent runners: effects of exercise intensity and duration. Int J Sports Med 2009;30:168-72.

82. Tian Y, Nie J, Huang C, George KP. The kinetics of highly sensitive cardiac troponin T release after prolonged treadmill exercise in adolescent and adult athletes. J Appl Physiol 2012;113:418-25.

83. Wedin JO, Henriksson AE. Postgame elevation of cardiac markers among elite floorball players. Scand J Med Sci Sports 2015;25:495-500.

84. Scharhag J, Urhausen A, Schneider G, Herrmann M, Schumacher $\mathrm{K}$, Haschke M, et al. Reproducibility and clinical significance of exercise-induced increases in cardiac troponins and $\mathrm{N}$-terminal pro brain natriuretic peptide in endurance athletes. Eur J Cardiovasc Prev Rehabil 2006;13:388-97.

85. Lippi G, Schena F, Dipalo M, Montagnana M, Salvagno GL, Aloe $R$, et al. Troponin I measured with a high sensitivity immunoassay is significantly increased after a half marathon run, Scand J Clin Lab Invest 2012;72:467-70.

86. Duttaroy S, Thorell D, Karlsson L, Borjesson M. A single-bout of one-hour spinning exercise increases troponin T in healthy subjects. Scand Cardiovasc J 2012;46:2-6.

87. Leers MP, Schepers R, Baumgarten R. Effects of a long-distance run on cardiac markers in healthy athletes. Clin Chem Lab Med 2006;44:999-1003.

88. Middleton N, Shave R, George K, Whyte G, Simpson R, FloridaJames $\mathrm{G}$, et al. Impact of repeated prolonged exercise bouts on cardiac function and biomarkers. Med Sci Sports Exerc 2007;39:83-90.

89. Mair J, Wohlfarter T, Koller A, Mayr M, Artner-Dworzak E, Puschendorf B. Serum cardiac troponin T after extraordinary endurance exercise. Lancet 1992;340:1048. 
90. Melanson SE, Green SM, Wood MJ, Neilan TG, Lewandrowski EL. Elevation of myeloperoxidase in conjunction with cardiac-specific markers after marathon running. Am J Clin Pathol 2006;126:888-93.

91. Bleier J, Vorderwinkler K-P, Falkensammer J, Mair P, Dapunt O, Puschendorf B, et al. Different intracellular compartmentations of cardiac troponins and myosin heavy chains: a causal connection to their different early release after myocardial damage. Clin Chem 1998;44:1912-8.

92. Jaffe AS, Vasile VC, Milone M, Saenger AK, Olson KN, Apple FS. Diseased skeletal muscle: a noncardiac source of increased circulating concentrations of cardiac troponin T. J Am Coll Cardiol 2011;58:1819-24.

93. Hughes M, Lilleker JB, Herrick AL, Chinoy H. Cardiac troponin testing in idiopathic inflammatory myopathies and systemic sclerosis-spectrum disorders: biomarkers to distinguish between primary cardiac involvement and low-grade skeletal muscle disease activity. Ann Rheum Dis 2015;74:795-8.

94. Olivetti G, Giordano G, Corradi D, Melissari M, Lagrasta C, Gambert SR, et al. Gender differences and aging: effects on the human heart. J Am Coll Cardiol 1995;26:1068-79.

95. Terman A, Brunk UT. Autophagy in cardiac myocyte homeostasis, aging, and pathology. Cardiovasc Res 2005;68:355-65.

96. Buja LM, Vela D. Cardiomyocyte death and renewal in the normal and diseased heart. Cardiovasc Pathol 2008;17:349-74.

97. Bergmann O, Bhardwaj RD, Bernard S, Zdunek S, BarnabéHeider F, Walsh S, et al. Evidence for cardiomyocyte renewal in humans. Science 2009;324:98-102.

98. Sahin E, DePnho RA. Linking functional decline of telomeres, mitochondria and stem cells during ageing. Nature 2010;464:520-8.

99. Torella D, Rota M, Nurzynska D, Musso E, Monsen A, Shiraishi I, et al. Cardiac stem cell and myocyte aging, heart failure, and Insulin-Like Growth Factor-1 overexpression. Circ Res 2004;94:514-24.

100. Kostin S. Cardiac telocytes in normal and diseased hearts. Semin Cell Dev Biol 2016;55:22-30.

101. Popescu LM, Curici A, Wang E, Zhang H, Hu S, Gherghiceanu M. Telocytes and putative stem cells in ageing human heart. J Cell Mol Med 2015;19:31-45.

102. Richter M, Kostin S. The failing human heart is characterized by decreased numbers of telocytes as result of apoptosis and altered extracellular matrix composition J Cell Mol Med 2015;19:2597-606.

103. McKie PM, Heublein DM, Scott CG, Gantzer ML, Mehta RA, Rodeheffer RJ, et al. Defining high sensitivity cardiac troponin concentrations in the community. Clin Chem 2013;59:1099-107.

104. Eggers KM, Lind L, Ahlström H, Bjerner T, Ebeling Barbier C, Larsson A, et al. Prevalence and pathophysiological mechanisms of elevated cardiac troponin I levels in a populationbased sample of elderly subjects. Eur Heart J 2008;29:2252-8.

105. Sinning C, Keller T, Zeller T, Ojeda F, Schlüter M, Schnabel R, et al. Association of high-sensitivity assayed troponin I with cardiovascular phenotypes in the general population: the population-based Gutenberg health study. Clin Res Cardiol 2014;103:211-22.

106. Bossard M, Thériault S, Aeschbacher S, Aeschbacher S, Schoen T, Kunz S, et al. Factors independently associated with cardiac troponin I levels in young and healthy adults from the general population. Clin Res Cardiol 2017;106:96-104.
107. Wildi K, Gimenez MR, Twerenbold R, Reichlin T, Jaeger C, Heinzelmann A, et al. Misdiagnosis of myocardial infarction related to limitations of the current regulatory approach to define clinical decision values for cardiac troponin. Circulation 2015;131:2032-40.

108. Chaitman BR. Is the 99th percentile the optimal reference limit to diagnose myocardial infarction with high-sensitivity cardiac troponin assays in patients with chronic kidney disease? Circulation 2015;131:2029-31.

109. Giannitsis E, Katus HA. Off limits: highly sensitive troponin in the general population. Eur Heart J 2016;3737:2438-40.

110. de Lemos JA, Drazner MH, Omland T, Ayers CR, Khera A, Rohatgi A, et al. Association of troponin T detected with a highly sensitive assay and cardiac structure and mortality risk in the general population. J Am Med Assoc 2010;304:2503-12.

111. Wang TJ, Wollert KC, Larson MG, Coglianese E, McCabe EL, Cheng S, et al. Prognostic utility of novel biomarkers of cardiovascular stress: the Framingham Heart Study. Circulation 2012;126:1596-604.

112. Everett BM, Zeller T, Glynn RJ, Ridker PM, Blankenberg S. Highsensitivity cardiac troponin I and B-type natriuretic peptide as predictors of vascular events in primary prevention: impact of statin therapy. Circulation 2015;131:1851-60.

113. Blankenberg S, Salomaa V, Makarova N, Ojeda F, Wild P, Lackner KJ, et al. Troponin I and cardiovascular risk prediction in the general population: the BiomarCaRE consortium. Eur Heart J 2016;37:2428-37.

114. Marshall DA, O’Brien BJ. Economic evaluation of diagnostic tests. In: Price CP, Christenson RH, editors. Evidence-Based Laboratory Medicine. From principle to outcomes. Washington DC: AACCPress, 2003: 159-86.

115. Pickering JW, Greenslade JH, Cullen L, Flaws D, Parsonage W, Aldous S, et al. Assessment of the European Society of Cardiology 0-hour/1-hour algorithm to rule-out and rule-in acute myocardial infarction. Circulation 2016;134:1532-41.

116. Shah AS, Griffiths M, Lee KK, McAllister DA, Hunter AL, Ferry AV, et al. High sensitivity cardiac troponin and the under-diagnosis of myocardial infarction in women: prospective cohort study. $\mathrm{Br}$ Med J 2015;350:g7873.

117. Giannitsis E. Gender-specific troponin measures for diagnosis of acute coronary syndrome. Heart 2016;102:91-2.

118. Mueller-Hennessen M, Lindahl B, Giannitsis E, Biener M, Vafaie $M$, deFilippi $C R$, et al. Diagnostic and prognostic implications using age- and gender-specific cut-offs for high-sensitivity cardiac troponin T - Sub-analysis from the TRAPID-AMI study. Int J Cardiol 2016;209:26-33.

119. Kawut SM, Lima JA, Barr RG, Chahal H, Jain A, Tandri H, et al. Gender and race differences in right ventricular structure and function: the multi-ethnic study of atherosclerosis-right ventricle study. Circulation 2011;123:2542-51.

120. Koerbin G, Abhayaratna WP, Potter JM, Apple FS, Jaffe AS, Ravalico TH, et al. Effect of population selection on 99th percentile values for a high sensitivity cardiac troponin I and T assays. Clin Biochem 2013;46:1636-43.

121. Aw TC, Phua SK, Tan SP. Measurement of cardiac troponin I in serum with a new high-sensitivity assay in a large multiethnic Asian cohort and the impact of gender. Clin Chim Acta 2013;422:26-8.

122. Collinson PO, Gaze D, Goodacre S. The clinical and diagnostic performance characteristics of the high 
sensitivity Abbott cardiac troponin I assay. Clin Biochem 2015;59:275-81.

123. Lee K, Lee SY, Choi JO, Jeon ES, Park HD. The distribution of Abbott high sensitivity troponin I levels in Korean patients with chest pain. Ann Clin Lab Sci 2015;45:152-7.

124. Kimenai DM, Henry RM, van der Kallen CJ, Dagnelie PC, Schram MT, Stehouwer CD, et al. Direct comparison of clinical decision limits for cardiac troponin T and I. Heart 2016;102:610-6.

125. Ji M, Moon HW, Hur M, Yun YM. Determination of high-sensitivity cardiac troponin I 99th percentile upper reference limits in a healthy Korean population. Clin Biochem 2016;49:756-61.

126. Ungerer JP, Tate JR, Pretorius CJ. Discordance with 3 cardiac troponin I and T assays: Implications for the 99th percentile cutoff. Clin Chem 2016;62:1106-14.

127. Giannitsis E, Kurz K, Hallermayer K, Jarausch J, Jaffe AS, Katus HA. Analytical validation of a high-sensitivity cardiac troponin T assay. Clin Chem 2010;56:254-61.

128. Gaggin HK, Dang PV, Do LD, deFilippi CR, Christenson RH, Lewandrowski EL, et al. Reference interval evaluation of highsensitivity troponin $\mathrm{T}$ and $\mathrm{N}$-terminal B-type natriuretic peptide in Vietnam and the US: The North South East West trial. Clin Chem 2014;60:758-64.

129. Fahie-Wilson MN, Carmichael DJ, Delaney MP, Stevens PE, Hall EM, Lamb EJ. Cardiac troponin T circulates in the free, intact form in patients with kidney failure. Clin Chem 2006;52:414-20.

130. Streng AS, Jacobs LH, Schwenk RW, Cardinaels EP, Meex SJ, Glatz JF, et al. Cardiac troponin in ischemic cardiomyocytes: intracellular decrease before onset of cell death. Exp Mol Pathol 2014;96:339-45.

131. Cardinaels EP, Mingels AM, van Rooij T, Collinson PO, Prinzen FW, van Dieijen-Visser MP. Time-dependent degradation pattern of cardiac troponin T following myocardial infarction. Clin Chem 2013;59:1083-90.

132. Solecki K, Dupuy AM, Kuster N, Leclercq F, Gervasoni R, Macia JC, et al. Kinetics of high-sensitivity cardiac troponin T or troponin I compared to creatine kinase in patients with revascularized acute myocardial infarction. Clin Chem Lab Med 2015;53:707-14.

133. Laugaudin G, Kuster N, Petiton A, Leclercq F, Gervasoni R, Macia JC, et al. Kinetics of high-sensitivity cardiac troponin $T$ and I differ in patients with ST-segment elevation myocardial infarction treated by primary coronary intervention. Eur Heart J Acute Cardiovasc Care 2016;5:354-63.

134. Klinkenberg LJ, Wildi K, van der Linden N, Kouw IW, Niens M, Twerenbold R, et al. Diurnal rhythm of cardiac troponin: consequences for the diagnosis of acute myocardial infarction. Clin Chem 2016;62:1602-11.

135. Kavsak PA, Shortt C, Pond G, Worster A. High-sensitivity cardiac troponin I for predicting death in a female emergency department population. Clin Chem 2014;60:271-3.

136. Bohula May EA, Bonaca MP, Jarolim P, Antman EM, Braunwald E, Giugliano RP, et al. Prognostic performance of a high-sensitivity cardiac troponin I assay in patients with non-ST-elevation acute coronary syndrome. Clin Chem 2014;60:158-64.

137. Eggers KM, Johnston N, James S, Lindahl B, Venge P. Cardiac troponin I levels in patients with non-ST-elevation acute coronary syndrome-the importance of gender. Am Heart J 2014;168:317-324.e1.
138. Cullen L, Greenslade JH, Carlton EW, Than M, Pickering JW, Ho A, et al. Gender-specific versus overall cut points for a high sensitivity troponin I assay in predicting 1-year outcomes in emergency patients presenting with chest pain. Heart 2016;102:120-6.

139. Rubini GM, Twerenbold R, Boeddinghaus J, Nestelberger T, Puelacher C, Hillinger P, et al. Clinical effect of gender-specific cutoff values of high-sensitivity cardiac troponin T in suspected myocardial infarction. JAMA Cardiol 2016;1:912-20.

140. Greenland P, Alpert JS, Beller GA, Benjamin EJ, Budoff MJ, Fayad ZA, et al. 2010 ACCF/AHA guideline for assessment of cardiovascular risk in asymptomatic adults: a report of the American College of Cardiology Foundation/American Heart Association Task Force on Practice Guidelines. J Am Coll Cardiol 2010;56:e50-103.

141. Ng A, Swanevelder J. Resolution in ultrasound imaging. Contin Educ Anaesth Crit Care Pain 2011;11:186-92.

142. Prakken NH, Teske AJ, Cramer MJ, Mosterd A, Bosker AC, Mali WP, et al. Head-to-head comparison between echocardiography and cardiac MRI in the evaluation of the athlete's heart. $\mathrm{Br}$ J Sports Med 2012;46:348-54.

143. Emdin M, Passino C, Prontera C, Fontana M, Poletti R, Gabutti A, et al. Comparison of Brain Natriuretic Peptide (BNP) and amino-terminal ProBNP for early diagnosis of heart failure. Clin Chem 2007;53:1289-97.

144. Hayward CS, Webb CM, Collins P. Effect of gender hormones on cardiac mass. Lancet 2001;357:1354-56.

145. Clerico A, Fontana M, Vittorini S, Emdin M. The search for a pathophysiological link between gender, cardiac endocrine function, body mass regulation and cardiac mortality: proposal for a working hypothesis. Clin Chim Acta 2009;405:1-7.

146. Clerico A, Giannoni A, Vittorini S, Passino C. Thirty years of the heart as an endocrine organ: physiological role and clinical utility of cardiac natriuretic hormones. Am J Physiol Heart Circ Physiol 2011;301:H12-20.

147. Zeller T, Hughes M, Tuovinen T, Schillert A, Conrads-Frank A, Ruijter HD, et al. BiomarCaRE: rationale and design of the European BiomarCaRE project including 300,000 participants from 13 European countries. Eur J Epidemiol 2014;29:777-90.

148. Altman DG, Royston P. The cost of dichotomizing continuous variables. Br Med J 2006;332:1080.

149. Mureddu GF, Tarantini L, Agabiti N, Faggiano P, Masson S, Latini R, et al. Evaluation of different strategies for identifying asymptomatic left ventricular dysfunction and pre-clinical (stage B) heart failure in the elderly. Results from 'PREDICTOR', a population based-study in central Italy. Eur J Heart Fail 2013;15:1102-12.

150. Manning WJ. Asymptomatic aortic stenosis in the elderly: a clinical review. J Am Med Assoc 2013;310:1490-7.

151. Stein JH, Korcarz CE, Hurst RT, Lonn E, Kendall CB, Mohler $E R$, et al. Use of carotid ultrasound to identify subclinical vascular disease and evaluate cardiovascular disease risk: a consensus statement from the American Society of Echocardiography Carotid Intima-Media Thickness Task Force. Endorsed by the Society for Vascular Medicine. J Am Soc Echocardiogr 2008;21:93-111. 